\title{
Approach to the most prevalent oral disorders among the elderly: an integrative review focusing on primary health care
}

\author{
Helena Pereira Rodrigues da Silva ${ }^{\top}$ \\ Bárbara Koppe ${ }^{2}$ \\ Myrian Câmara Brew ${ }^{3}$ \\ Giordano Santana Sória ${ }^{4}$ \\ Caren Serra Bavaresco ${ }^{5}$
}

Abstract

Objective: an integrative review of the treatment of oral candidiasis, root caries and xerostomia among the elderly population, focusing on Primary Health Care, was carried out. Method: scientific articles were collected from the MEDLINE/PUBMED database using the keywords "Geriatric dentistry" and "Oral health", crossed with corresponding descriptors, together with specific terms for the pathologies studied, and with "the clinical trial" filter activated. The abstracts of the articles were read by three researchers. Result: oral candidiasis: six randomized clinical trials and one quasi-experimental design study, on the treatment of prosthetic stomatitis by medication and/or the disinfection of dentures by different techniques, were identified; root caries: three randomized clinical trials were included, which tested the use of mouthwash with chlorhexidine solution and oral hygiene instruction associated or otherwise with other drugs; and xerostomia: two articles were analyzed using various medications, and the functional massage of the salivary glands and associated muscles. Conclusion: The results demonstrate a variety of treatment options for the studied clinical situations, although these should be adapted to the characteristics of the services and the population, as standard treatment in Primary Health Care has not been established. Strategies based on soft technologies, such as health education, seem to provide good results. The present study provides additional knowledge for health professionals in search of more resolutive and qualified dental care for the elderly in primary health care.

\footnotetext{
Prefeitura Municipal de Novo Hamburgo. Departamento de Atenção Básica. Novo Hamburgo, RS, Brasil. Prefeitura Municipal de Porto Alegre, Departamento de Atenção Básica. Porto Alegre, RS, Brasil

Universidade Luterana do Brasil, Faculdade de Odontologia. Canoas, RS, Brasil

Universidade Federal de Pelotas, Departamento de Epidemiologia. Pelotas, RS, Brasil

5 Universidade Luterana do Brasil, Faculdade de Odontologia, Programa de Pós-Graduação em Odontologia. Canoas, RS, Brasil

Correspondence

Caren Serra Bavaresco.

E-mail: c_bavaresco@yahoo.com.br
}

Keywords: Candidiasis, Oral. Root Caries. Xerostomia. Primary Health Care. Elderly. Oral Health. 


\section{INTRODUCTION}

Oral health care in Brazil has historically prioritized the health of schoolchildren, leaving population groups such as the elderly on the margins of public policies in this area ${ }^{1}$. This group of patients has become a serious public health problem, and the increased longevity and the high disease burden of the elderly population in Brazil have brought several problems related to the dental care of these patients to the fore.

The dental care of the elderly becomes more complex given the demographic transition of population aging in Brazil over the last 50 years, a phenomenon which has occurred in parallel with the epidemiological transition ${ }^{2}$. As mortality from infectious diseases decreases, the life expectancy of the population increases, as people are exposed for a longer period to risk factors and the prevalence of chronic-degenerative diseases increases ${ }^{3}$. This causes the health-disease profile of the population to change, requiring the reorganization and restructuring of health systems to meet this different type of demand ${ }^{4}$.

This fact can be observed in an epidemiological survey which showed that the elderly population had a decayed, missing and filled teeth index (DMFT) of approximately 27 , which is extremely high, with a predominance of the "missing" component and a major need for prosthetic rehabilitation. The proportion of individuals aged 65 to 74 years who did not need some type of dental prosthesis was only $7.3 \%$. This situation is a reflection of the old invasive odontological practice, which did not emphasize conservative treatments and the prevention of injuries ${ }^{5}$.

Although public policies have been reorganized and reoriented through emphasis on the role of Primary Health Care (PHC) and the shift of the coordination of care to this level, the inherent complexity of health care among the elderly population poses challenges to the work of PHC health teams.

PHC is the first level of care provided by the health system and aims to resolve the most frequently occurring problems among the population ${ }^{6}$. In Brazil, the number of dentists in basic care has increased considerably, also improving the use of oral health services?

Despite the advances achieved in terms of increasing the public dental service, there are many difficulties in the organization of oral health care for the elderly. According to Oliveira et al. ${ }^{8}$, due to the model of oral health care instituted in Brazil in recent decades, which features a predominance of exodontia in detriment of conservative procedures, the rate of edentulism in the elderly population has reached extremely high levels, as has as the presence of xerostomia ${ }^{9}$ and root caries ${ }^{10,11}$.

Xerostomia can be considered as the subjective complaint of dry mouth, and is clinically diagnosed through the sialometry test. Hyposalivation is considered salivary flow rates below $0.1 \mathrm{~mL} / \mathrm{min}$ at rest or $0.7 \mathrm{~mL} / \mathrm{min}$ under stimulation ${ }^{12}$. This condition can bring considerable oral discomfort and difficulty in chewing, swallowing, speaking and the wearing of dentures, as well as a burning sensation or even local pain, in addition to an increased chance of caries, candidiasis or other opportunistic infections ${ }^{13}$. The main cause of xerostomia in the elderly is the use of certain drugs, such as tricyclic antidepressants, sedatives, antihistamines and antihypertensive medication among others ${ }^{12}$. In addition to this factor, the functioning of the salivary glands can decrease with advancing age ${ }^{13}$.

In this context, Wolff et al. ${ }^{14}$ report that the increased risk for the onset of the sensation of pain in the oral mucosa, candidiasis and dental caries is associated with salivary flow reduction.

In dentistry, the most significant fungus is a yeast belonging to the Candida genus. Under normal conditions, it is a commensal organism and is present in about half of the population, causing no apparent damage nor inducing inflammation in adjacent tissues. However, under certain host conditions, the fungus multiplies, penetrates tissues, causes inflammation and becomes a pathogen. Among the species of the Candida genus found in humans, Candida albicans is responsible for the majority of infections. Factors related to the change from commensal organisms to pathogens may be predisposing, such as alterations in the buccal environment (poor hygiene and xerostomia) ${ }^{15}$. 
Turning to dental caries, Rösing and Jardim ${ }^{16}$ consider these to be an increasing epidemiological problem due to the dental maintenance throughout the life of individuals. The authors emphasize the importance of the careful observance of this problem by dentistry professionals and the adoption of effective preventive and restorative approaches

From this perspective, the need for professional training and the stimulation of the practice of evidence-based dentistry is fundamental. It is imperative that PHC oral health teams are able to correctly diagnose and treat the most common oral problems in the growing elderly population, considering the uniqueness of the physical and mental condition and the complexity of the dental treatment of these individuals. The present study therefore aimed to present an integrative review of the treatment of oral candidiasis, root caries and xerostomia, with a focus on PHC.

\section{METHOD}

A literature search was conducted of articles dealing with the treatment of oral candidiasis, root caries and xerostomia among the elderly population, irrespective of comorbidities. The MEDLINE/ PUBMED, BIREME, LILACS and SciELO databases were used to achieve this. No articles were found in the BIREME, LILACS and SciELO databases that dealt with the subjects chosen based on geriodontics and with a focus on PHC.

The descriptors "Geriatric dentistry" and "Oral health" were chosen for the search and were crossed with the descriptors of the three pathologies, including all the respective "entry terms" in this crossing. In the search for candidiasis only, the crossing with "Oral health" was removed, due to the low number of articles that were found. Articles published in the period from $01 / 2004$ to $10 / 2016$ were included. The "Clinical trial" filter was activated in all searches. Articles were not excluded based on the language of the publication.

For the search in the MEDLINE/PUBMED databases, in relation to candidiasis the terms "Geriatric dentistry" [Mesh] OR "Dentistry, Geriatric" OR "Dental Care for Aged" OR

"Dentistry for Aged" OR "Aged, Dentistry for" OR "Dental Care for Elderly" AND ("Candidiasis, Oral" [Mesh] OR "Candidiases, Oral" OR "Oral Candidiases" OR "Oral Candidiasis" OR "Thrush" OR "Moniliasis, Oral” OR "Moniliases, Oral” OR "Oral Moniliases" OR “Oral Moniliasis”) were used.

In the same database, for the search on root caries, the terms "Geriatric dentistry" [Mesh] OR "Dentistry, Geriatric" OR "Dental Care for Aged" OR "Dentistry for Aged" OR "Aged, Dentistry for" OR "Dental Care for Elderly" AND ("Oral Health" [Mesh] OR "Health, Oral" AND ("Root Caries" [Mesh] OR "Caries, Root" OR "Caries, Cervical" OR "Cary, Cervical" OR "Cervical Cary" OR "Cervical Caries")) were used.

For the search on xerostomia, we used the terms "Geriatric dentistry" [Mesh] OR "Dentistry, Geriatric" OR "Dental Care for Aged" OR "Dentistry for Aged" OR "Aged, Dentistry for" OR "Dental Care for Elderly" AND ("Oral Health" [Mesh] OR "Health, Oral" AND ("Xerostomia" [Mesh] OR "Xerostomias" OR "Hyposalivation" OR "Hyposalivations" OR "Asialia" OR "Asialias" OR “Mouth Dryness" OR “Dryness, Mouth”)).

Summaries of all the articles found were read by three independent researchers who excluded those which did not deal with subjects related to geriodontics, or were not within the scope of PHC activities or had obvious methodological problems in terms of the items on Cochrane's checklist (reference) described by Carvalho et al. ${ }^{18}$. The selected articles were characterized according to design, place of research, year of publication and the results found.

\section{RESULTS}

\section{Oral Candidiasis}

The search for candidiasis resulted in 22 articles. The abstracts were analyzed by three examiners, who excluded 10 articles, leaving 12 . After reading the articles in full, four were excluded due to methodological problems or the age group of the sample. Eight articles remained for analysis.

The papers on candidiasis comprised seven randomized clinical trials and one quasi-experimental study. The study samples ranged from 27 to 215 
patients. The randomized clinical trials included different treatment proposals for denture-related stomatitis. In four studies, different drug treatments were tested, while in two only types of disinfection of dentures were tested as a treatment for candidiasis. In one study, drug therapy and a form of denture disinfection were tested. Another study evaluated the effect of daily probiotic use on the prevalence of Candida Albicans. Both the study by Neppelenbroek et al. ${ }^{19}$ and the study by Webb et al. ${ }^{20}$ addressed only denture disinfection techniques as a form of candidiasis treatment, and both had positive results (Chart 1).

Chart 1. Description of articles on oral candidiasis. Porto Alegre, Rio Grande do Sul, 2016

\begin{tabular}{|c|c|c|}
\hline Authors/Year/Country & Sample and Methodology & Results \\
\hline $\begin{array}{l}\text { Webb BC et al., } 2005^{20} \\
\text { (Australia) }\end{array}$ & $\begin{array}{l}60 \text { patients with candida-associated } \\
\text { denture stomatitis; Two test groups and } \\
\text { one control group. Randomized clinical } \\
\text { trial; Efficacy of two treatment methods. }\end{array}$ & $\begin{array}{l}\text { The control group showed insignificant changes } \\
\text { in the candida and aerobic bacteria counts on } \\
\text { dentures. Both hypochlorite and microwave } \\
\text { irradiation proved to be effective in combating } \\
\text { candida-associated denture stomatitis. }\end{array}$ \\
\hline $\begin{array}{l}\text { Koray M et al., } 2005^{48} \\
\text { (Turkey) }\end{array}$ & $\begin{array}{l}61 \text { patients; Three groups (fluconazole, } \\
\text { hexetidine and fluconazole }+ \text { hexetidine). } \\
\text { Quasi-experiment; Efficacy of oral } \\
\text { fluconazole and hexetidine }\end{array}$ & $\begin{array}{l}\text { The three groups showed a significant } \\
\text { reduction compared to pre-test. There were no } \\
\text { significant differences between groups. }\end{array}$ \\
\hline $\begin{array}{l}\text { Catalán A et al., } 2008^{34} \\
\text { (Chile) }\end{array}$ & $\begin{array}{l}27 \text { patients with stomatitis; nine per } \\
\text { group (two tests and one control). } \\
\text { Randomized clinical trial; Antifungal } \\
\text { effect of melaleuca alternifolia }\end{array}$ & $\begin{array}{l}\text { In vitro: melaleuca - total inhibition of candida. } \\
\text { In vivo: two test groups - no statistical } \\
\text { difference; test groups compared to control } \\
\text { group - both reduced the signs of inflammation. }\end{array}$ \\
\hline $\begin{array}{l}\text { Neppelenbroek KH et } \\
\text { al. } 2008^{19} \\
\text { (Brazil) }\end{array}$ & $\begin{array}{l}60 \text { patients; three test groups (Mw - } \\
\text { micro-waves, Mz-miconazole and } \mathrm{MwMz}) \\
\text { and a control group. Randomized clinical } \\
\text { trial; Effectiveness of disinfection } \\
\text { of complete upper dentures through } \\
\text { microwave irradiation. }\end{array}$ & $\begin{array}{l}\text { Mw and MwMz had much better results than } \\
\text { control and Mz. } \\
\text { There was no significant difference between } \\
\text { the Mw and MwMz groups }\end{array}$ \\
\hline $\begin{array}{l}\text { Meurman JH et al., } \\
2009^{50} \\
\text { (Finland) }\end{array}$ & $\begin{array}{l}194 \text { patients, two groups (control group } \\
\text { with placebo and test group with AmF- } \\
\text { SnF2 solution). Randomized clinical } \\
\text { trial; Antifungal effect of amine flouride- } \\
\text { stannous fluoride combination (AmF- } \\
\text { SnF2) in solution compared to placebo }\end{array}$ & $\begin{array}{l}\text { The number of patients with high candida } \\
\text { counts was lower in the test group than in the } \\
\text { control group. Total bacterial count was lower in } \\
\text { both groups. The use of the AmF-SnF2 solution } \\
\text { did not significantly change the mean candida } \\
\text { score but the median was reduced in this group, } \\
\text { while there was an increase in the control group. }\end{array}$ \\
\hline $\begin{array}{l}\text { Khozeimeh F et al., } \\
2010^{49} \\
\text { (Iran) }\end{array}$ & $\begin{array}{l}30 \text { patients from a geriatric sanatorium, } \\
\text { two groups (topical ketoconazole } \\
\text { group and ketoconazole tablet group). } \\
\text { Randomized clinical trial, efficacy } \\
\text { between topical ketoconazole } 2 \% \text { in } \\
\text { orabase and ketoconazole tablet. }\end{array}$ & The treatments exhibited similar efficacy. \\
\hline $\begin{array}{l}\text { Mima EG et al., } 2012^{35} \\
\text { (Brazil) }\end{array}$ & $\begin{array}{l}40 \text { edentulous patients with dentures; Two } \\
\text { groups: Nystatin Group and PDT Group. } \\
\text { Randomized clinical trial; Compares the } \\
\text { action of photodynamic therapy (PDT) } \\
\text { and topical antifungal treatment against } \\
\text { denture stomatitis, in terms of fungus } \\
\text { count. Identification of species of candida. }\end{array}$ & $\begin{array}{l}\text { Nystatin success: } 54 \% \text {. PDT success: } 45 \% \text {. } \\
\text { Both reduced fungal culture in } 30 \text { days (with } \\
\text { no statistical difference between groups). } \\
\text { There were recurrence rates of } 75 \% \text { (Nyst) and } \\
78 \% \text { (PDT) among successful cases. }\end{array}$ \\
\hline $\begin{array}{l}\text { Kraft -Bodi E et al. } \\
2015^{36} \\
\text { (Switzerland) }\end{array}$ & $\begin{array}{l}215 \text { elderly residents in nursing homes, } \\
\text { two analysis groups (group using two } \\
\text { types of probiotics and a placebo group). } \\
\text { Randomized Double Blind Two-Arm } \\
\text { Clinical Trial; effect of probiotic use on } \\
\text { the prevalence and counts of oral candida. }\end{array}$ & $\begin{array}{l}\text { Significant reduction in the prevalence of } \\
\text { Candida Albicans in both dental biofilm and } \\
\text { saliva }(p<0.05) \text {. There was no difference } \\
\text { between gingival bleeding and dental biofilm } \\
\text { levels. }\end{array}$ \\
\hline
\end{tabular}




\section{Root caries}

The search for articles on root caries (Chart 2) resulted in 14 articles: eight were excluded after reading the abstract and one was excluded after a complete reading, leaving five articles for analysis. The resulting articles are randomized clinical trials with samples of 266 to 1101 participants.

Chart 2. Description of articles about root caries. Porto Alegre, Rio Grande do Sul, 2016

\begin{tabular}{|c|c|c|}
\hline Authors/Year/Country & Sample and methodology & Results \\
\hline $\begin{array}{l}\text { Wyatt CC et al., } 2007^{21} \\
\text { (Canada) }\end{array}$ & $\begin{array}{l}\text { 1,101 elderly persons; Two groups: control } \\
\text { group (placebo) - } 551 \text { elderly persons; CHX } \\
\text { (chlorhexidine) test group - } 550 \text { elderly } \\
\text { persons. Randomized double-blind clinical } \\
\text { trial; tests the impact of regularly rinsing with } \\
0.12 \% \text { chlorhexidine solution on tooth loss. }\end{array}$ & $\begin{array}{l}\text { Results showed that regular use of } \\
\text { chlorhexidine mouthwash did not have a } \\
\text { substantial effect on the preservation of } \\
\text { dental structures among the elderly. }\end{array}$ \\
\hline $\begin{array}{l}\text { Tan HP et al., } 2010^{22} \\
\text { (China) }\end{array}$ & $\begin{array}{l}306 \text { elderly persons from } 21 \text { institutions; } \\
\text { four groups: Individual hygiene instruction } \\
\text { (IHI); IHI + application of chlorhexidine } \\
1 \% \text { varnish every three months; IHI + 5\% } \\
\text { sodium fluoride varnish application every } \\
\text { three months; IHI + annual application } \\
\text { of } 38 \% \text { silver fluoride diamine solution. } \\
\text { Randomized clinical trial; to compare the } \\
\text { efficacy of four methods of preventing new } \\
\text { root caries. }\end{array}$ & $\begin{array}{l}\text { Groups two, three and four had reduced } \\
\text { carious surfaces in comparison to the } \\
\text { IHI only group (reduction of relative } \\
\text { risk of caries). There was no significant } \\
\text { difference between groups. Reductions } \\
\text { of } 57 \%, 64 \% \text {, and } 71 \% \text { respectively. Side } \\
\text { effects or discomfort were not reported. }\end{array}$ \\
\hline $\begin{array}{l}\text { Zhang W et al., } 2013^{23} \\
\text { (China) }\end{array}$ & $\begin{array}{l}266 \text { elderly persons; three groups: Group } \\
\text { One: OHI annually; - Group Two: OHI } \\
\text { and application of SFD annually; Group } \\
\text { Three: OHI and SFD annually and another } \\
\text { oral health education program (OHEP) } \\
\text { every six months. Randomized clinical } \\
\text { trial; To evaluate the effectiveness of silver } \\
\text { fluoride diamine (SFD) and education on the } \\
\text { prevention and paralysis of root caries lesions. }\end{array}$ & $\begin{array}{l}\text { Group three had fewer new carious } \\
\text { surfaces than group one. } \\
\text { Group two and three had a greater number } \\
\text { of paralyzed caries than group one. }\end{array}$ \\
\hline $\begin{array}{l}\text { Cruz Gonzalez AC, } \\
\text { Marín Zuluaga DJ, } \\
2015^{24} \\
\text { (Colombia) }\end{array}$ & $\begin{array}{l}75 \text { elderly people living in geriatric } \\
\text { institutions; Two groups (ART and } \\
\text { conventional technique) evaluated after } \\
\text { six months. Randomized Clinical Trial; to } \\
\text { compare the clinical performance of the ART } \\
\text { technique in relation to the conventional } \\
\text { technique on root surfaces }\end{array}$ & $\begin{array}{l}\text { The ART group presented an } 81.3 \% \\
\text { survival rate after } 6 \text { months while the } \\
\text { conventional technique obtained a rate } \\
\text { of } 92.9 \% \text {. Although the ART group had } \\
\text { a higher rate of failure and less success in } \\
\text { terms of treatment, the authors suggest } \\
\text { that ART is a recommended technique } \\
\text { for the treatment of root caries in the } \\
\text { institutionalized elderly. }\end{array}$ \\
\hline $\begin{array}{l}\text { da Mata C.et al., } 2015^{25} \\
\text { (Ireland) }\end{array}$ & $\begin{array}{l}99 \text { elderly persons, two groups (ART and } \\
\text { conventional technique). Randomized } \\
\text { Controlled Clinical Trial with two-year } \\
\text { follow-up. }\end{array}$ & $\begin{array}{l}\text { The cumulative survival rate of the } \\
\text { restorations was } 85.4 \% \text { for ART and } \\
90.9 \% \text { for the conventional technique. } \\
\text { Statistical analysis did not find a } \\
\text { significant difference between groups. }\end{array}$ \\
\hline
\end{tabular}

Wyatt et al. ${ }^{21}$ tested the impact of regularly chewing a solution of chlorhexidine $0.12 \%$ among 550 elderly persons. All dental and crown surfaces were monitored for five years. Regular use of mouthwash was not effective in preventing new root caries.
Two studies had positive results for the prevention of root caries. Tan et al. ${ }^{22}$ tested four methods of preventing new root caries in 306 elderly people with at least five teeth in their mouths. The three agents tested (the application of chlorhexidine $1 \%$ varnish 
every three months, 5\% sodium fluoride varnish every three months and the silver fluoride diamine (SFD) solution 38\% annually - all combined with oral hygiene instruction) were found to be effective at preventing root caries.

Zhang et al. ${ }^{23}$ evaluated the effect of SFD and education on the prevention and paralysis of root caries in 266 elderly people with at least five teeth with exposed roots in the mouth. In addition, the study evaluated the synergistic effect of the Oral Health Education Program (OHEP) and SFD. The patients were accompanied for 24 months. The results showed that the biannual application of SFD and OHEP is more effective at preventing and paralyzing caries than only oral hygiene instruction, with a synergic effect between the two.

Cruz-Gonzalez and Zuluaga ${ }^{24}$ evaluated the effect of using the atraumatic restorative technique (ART) in comparison with the conventional technique in terms of the survival rate of the restorations. The authors suggest that ART is the technique of choice for the treatment of root caries in institutionalized elderly persons due to its high success rate and restoration survival rate $(81 \%)$ after six months. In this same context, Mata et al. ${ }^{25}$ described a survival rate of $85.4 \%$ in restorations performed with the ART technique after two years of followup in a randomized clinical trial performed with institutionalized elderly persons.

\section{Xerostomia}

Twenty-one articles about xerostomia resulted from the search, 16 of which were excluded after reading the abstract. After a complete reading of the articles, two were excluded, leaving three for analysis (Chart 3).

Chart 3 - Description of articles about xerostomia. Porto Alegre, Rio Grande do Sul, 2016

\begin{tabular}{|c|c|c|}
\hline Authors/Year/Country & Sample and methodology & Results \\
\hline $\begin{array}{l}\text { Gil-Montoya JÁ et al. } \\
2008^{26} \\
\text { (Spain) }\end{array}$ & $\begin{array}{l}20 \text { institutionalized elderly; Two phases: } \\
\text { Phase One: test group - Biotene mouthwash } \\
\text { and Oral Balance gel and control group } \\
\text { - two placebo products. Stage Two: after } \\
\text { a break of } 20 \text { days, the products were } \\
\text { changed. Pilot study. Randomized double } \\
\text { blind clinical trial; to evaluate the clinical } \\
\text { efficacy of a mouthwash and gel containing } \\
\text { the antimicrobial proteins lactoperoxidase, } \\
\text { lysozyme and lactoferrin in elderly patients } \\
\text { with dry mouth. }\end{array}$ & $\begin{array}{l}\text { Some symptoms improved with the test } \\
\text { group and others with the placebo. }\end{array}$ \\
\hline $\begin{array}{l}\text { Hakuta C et al., } 2009^{27} \\
\text { (Japan) }\end{array}$ & $\begin{array}{l}141 \text { elderly persons; Two groups: test } \\
\text { group - underwent program and control } \\
\text { group which did not undergo program. } \\
\text { Randomized clinical trial; evaluate oral } \\
\text { functionality promotion program for the } \\
\text { elderly in Japan with facial and tongue } \\
\text { exercises and massage of the salivary } \\
\text { glands. }\end{array}$ & $\begin{array}{l}\text { In the test group: the tongue coating scores } \\
\text { decreased; the amount of food debris in } \\
\text { the oral cavity was reduced and dryness on } \\
\text { the tongue was improved; the increase rate } \\
\text { of salivary flow was greater; the period of } \\
\text { time of the tongue being maintained in the } \\
\text { forward position increased and the number } \\
\text { of times for moving the tip of the tongue } \\
\text { increased; pronunciation of words was clearer. }\end{array}$ \\
\hline $\begin{array}{l}\text { Ohara Y et al., } 2015^{28} \\
\text { (Japan) }\end{array}$ & $\begin{array}{l}47 \text { elderly patients with xerostomia; Two } \\
\text { groups (the group that received the oral } \\
\text { health education program and the control } \\
\text { group). Randomized Clinical Trial; the } \\
\text { intervention group consisted of oral } \\
\text { hygiene instructions, muscular exercises } \\
\text { and massage of the salivary glands; the } \\
\text { control group received general information } \\
\text { about oral health. }\end{array}$ & $\begin{array}{l}21 \text { patients from the intervention group } \\
\text { and } 17 \text { patients from the control group } \\
\text { completed the study. The salivary } \\
\text { accumulation tests were significantly better } \\
\text { in the intervention group than the control } \\
\text { group. }\end{array}$ \\
\hline
\end{tabular}


Gil-Montoya et al. ${ }^{26}$ conducted a pilot study with 20 participants, which evaluated the clinical efficacy of a mouthwash and gel containing antimicrobial proteins, lactoperoxidase, lysozyme and lactoferrin in elderly patients with hyposalivation accompanied by xerostomia. Some symptoms improved with the test solution and others with the placebo, with no definitive result.

Hakuta et al. ${ }^{27}$ evaluated an oral functionality promotion program for the elderly in Japan, which consisted of facial and tongue exercises and massage of the salivary glands. The intervention group exhibited an improvement in the salivary flow rate, in addition to other functional gains. Recently, Ohara et al. ${ }^{28}$ performed a similar study using OHEP with 47 elderly patients with xerostomia. The authors demonstrated that educational strategies (oral hygiene instruction, salivary gland massage and muscular exercises for the tongue and face) are effective for the control of xerostomia. However, the test group did not exhibit a different result from the control group after three months of observation.

\section{DISCUSSION}

Candidiasis is the most common fungal infection of the mouth in humans and has varying degrees of severity ${ }^{13}$. The use of dentures is a modifying factor of the oral environment that is strongly related to infection ${ }^{29}$. Dentures alter the oral condition by reducing $\mathrm{pH}$, salivary flow and the contact of the tongue with tissues, as well as factors such as poor hygiene and the permanent use of the prosthesis during the night ${ }^{29}$. In addition, the acrylic surface serves as a reservoir for potentially pathogenic microorganisms, aggravating infection and allowing reinfection after treatment ${ }^{30}$.

The management of denture-related stomatitis is complex due to its multifactorial etiology ${ }^{13}$. Several drugs alleviate the symptoms and clinical signs of the infection, but are not sufficient to eradicate the fungus from the dentures, causing high recurrence rates due to reinfection ${ }^{31}$. In addition, systemic agents, such as ketoconazole, fluconazole and itraconazole may produce varied adverse effects and drug interactions ${ }^{32}$.
Although many studies have found a high rate of resistance to this drug, nystatin is still the first-choice treatment for candidiasis, and has been adopted by the Ministry of Health ${ }^{33}$. The studies by Catalan et al. ${ }^{34}$ and Mima et al. ${ }^{35}$ compared alternative therapies with Nystatin, and found equally positive results. The first tested the antifungal effect of the topical use of Melaleuca alternifolia and the second tested photodynamic therapy for the disinfection of dentures. Although the results were similar to nystatin, more research is needed on these subjects, as the studies have small samples. In addition, photodynamic therapy is expensive for consideration as treatment at a populational level. On the other hand, the proposed use of probiotics described by Kraft-Bodi et al. ${ }^{36}$ could represent an interesting therapeutic strategy in this population, in view of its effect on the reduction of strains of Candida Albicans.

Two studies included in this review show that disinfection of dentures without systemic or topical treatment was sufficient to treat candidiasis and recurrence. This represents a much more conservative line of treatment, with little intervention and drug use, compatible with the public health reality of Brazil.

The study by Neppelenbroek et al. ${ }^{19}$ tests microwave irradiation disinfection, which seems a highly promising method, but there is a need for more studies on the subject. Microwaves, when misused, can irreversibly damage dentures due to the increase in temperature ${ }^{37}$, and can be very harmful to the user. In addition, different power and time protocols for handling the microwave apparatus must be tested to maximize results and minimize risks.

The study by Webb et al. ${ }^{20}$ seems to be the most important among the studies found in relation to cost-benefit. It showed that immersion in a solution of water and sodium hypochlorite has the same disinfection power as the microwave technique, and is a much safer and cheaper approach.

In public health, priority should be given to the use of less invasive alternatives in the treatment of denture-related stomatitis, such as the recommendation of denture removal for sleeping, denture hygiene instructions and immersion of the dentures overnight in a solution of water and 
sodium hypochlorite. Medications should be used if there is no improvement following previous recommendations.

Most of the existing studies regarding caries address the disease in a younger population ${ }^{38}$, but more studies on root caries are now emerging, especially regarding the elderly population. Root caries occur due to the presence of plaque and food debris on the root surface of the teeth and are more prevalent among the dentate elderly, as the roots of the teeth tend to be exposed due to the sequelae of periodontal disease or the loss of insertion caused by age ${ }^{39}$. The World Health Organization recommends that countries urgently adopt strategies to improve the oral health of the elderly population, as dental treatment is the fourth most expensive type of treatment in industrialized countries, and successful prevention strategies are not implemented many nations will be unable to meet the cost of the necessary treatments for the population ${ }^{40}$.

In a large scale epidemiological survey of Brazilian oral health, a low level of root caries was found in the population aged 65 to 74 years, although the small number of remaining teeth in the population in this age group should be considered. Large differences among the regions of the country were verified, with the root caries index in the north and centerwest regions equal to twice the other regions of the country ${ }^{41}$. However, studies from other countries show a much higher prevalence, varying from 10.1\% to $40.6 \%$, with an average incidence among surveyed nations of $23.7 \%{ }^{42}$.

Both the article by Tan et $a .^{22}$ and Zhang et al. ${ }^{23}$ show very important and perfectly compatible results with the reality of the $\mathrm{PHC}$, with low-cost, low-invasive and highly-resolutive techniques.

The article by Tan et al. ${ }^{22}$ showed three types of treatment, compared to the control group, which featured only oral hygiene instruction. The methods tested proved to be quite effective in preventing new root caries and were simple to apply, allowing trained health professionals, other than dentistry professionals, to use them.

The study by Zhang et al. ${ }^{23}$ also uses SFD, but the differential of this study is the result of synergistic action with an OHEP, which occurred every six months in 30-minute meetings. The main objectives of the OHEP were to reduce habits of snacking outside meal times, learn correct methods of brushing and the use of additional teeth-cleaning tools.

Few studies have tested sodium fluoride varnish and SFD in the treatment of root caries, but these two agents demonstrate great efficacy in caries prevention in children and adolescents ${ }^{43}$. The major disadvantage of using SFD is that the product blackens the surface of the teeth, which, even among the elderly population, must be considered in a culture that values aesthetics such as ours.

A systematic review evaluated the effectiveness of chlorhexidine varnish in the prevention of root caries, and found that the agent is effective and has a greater impact on patients who do not receive prophylaxis and hygiene guidance systematically and among the institutionalized elderly ${ }^{44}$. In terms of oral health education, several evaluations have shown that the combination of the use of cariostatic agents with a program is probably an effective technique to combat root caries in the elderly population ${ }^{42}$.

On the other hand, the treatment of xerostomia has been essentially palliative, with saliva substitutes, non-pharmacological topical stimulation with candies or chewing gum without sugar, lubrication of mucosal tissues (such as with olive oil), or even nocturnal humidifiers. There are proposals for the systemic stimulation of the salivary glands with sialogogues (silicone devices that stimulate salivation by chewing). In addition, the use of fluorides and antimicrobials in the prevention of caries and periodontal disease in these patients is common. ${ }^{45}$.

The study by Hakuta et al. ${ }^{27}$ obtained excellent results with an oral functionality promotion program for the elderly. This consisted of six sessions of exercises of the facial muscles, tongue and salivary gland massage, with two sessions per month for three months. Although the reduction of xerostomia was not the sole objective of this program, it achieved good results in this respect. The type of strategy addressed in this study complies with the logic of health promotion, being a low cost and reproducible approach for the reality of PHC in Brazil. 
There are few studies on improving the mobility of the tongue and lips, among other aspects of oral functionality. It is important to note that health does not only mean the number of teeth present and the level of oral hygiene. Functional activities such as tongue and lip skills and salivary flow are also important elements. Impairment of these functions reduces masticatory efficacy, increases the risk of nutritional deficiencies, and decreases the pleasure of eating and communicating. These factors all influence the quality of life of the elderly and can lead to social isolation ${ }^{27}$.

The growing number of dentists working in the Estratégia Saúde da Família (the Family Health Strategy), the increase in the number of elderly people in the population and the greater use of the public dental service emphasize that the adaptation of PHC to the needs of this population is required. Historically, dentistry is a science based on empirical knowledge, ${ }^{46,47}$ but current trends and the increasing number of research studies are contributing to the development of evidence-based dentistry.

It is important to highlight the limitations of the present study, starting with the literature review itself. The small number of articles resulting from the searches shows a lack of randomized clinical trials on the subjects addressed, especially from

\section{REFERENCES}

1. Moreira RS, Nico LS, Tomita NE, Ruiz T. A saúde bucal do idoso brasileiro: revisão sistemática sobre o quadro epidemiológico e acesso aos serviços de saúde bucal. Cad Saúde Pública. 2005;21(6):1665-75.

2. Schramm JMA, Oliveira AF, Leite IC, Valente JG, Gadelha AMJ, Portela MC, et al. Transição epidemiológica e o estudo de carga de doença no Brasil. Ciênc Saúde Coletiva. 2004;9(4):897-908.

3. Frenk J, Frejka T, Bobadilla JL, Stern C, Lozano $\mathrm{R}$, Sepúlveda J, et al. La transición epidemiológica en América Latina. Bol Oficina Sanit Panam. 1991;111(6):485-96.
Brazil. The fact that most of the studies were excluded from the research after reading the abstracts shows that the studies on the subject do not follow a methodological standard and that the database used may need updating in terms of its descriptors, since several subjects appeared as search results. Consideration should also be given to publication bias, in which articles with positive results tend to be more published than articles with negative results. In this way, the results may be slightly overestimated.

\section{CONCLUSION}

The results demonstrate a variety of treatment options for the clinical situations highlighted, revealing that the characteristics of the services and population served should be evaluated, as a standard treatment for use in Primary Health Care has not been established. Strategies focused on mild, lowtech technologies such as health education seem to provide good results. The present study contributes to the knowledge of health professionals to provide increasingly resolutive and qualified dental care for the elderly in primary health care. It is suggested that more studies are carried out with a focus on primary care so that effective and adequate care protocols can be created for this population.
4. Chaimowicz F. A saúde dos idosos brasileiros às vésperas do século XXI: problemas, projeções e alternativas. Rev Saúde Pública. 1997;31(2):184-200.

5. BRASIL. Ministério da Saúde, Secretaria de Atenção à Saúde, Departamento de Atenção Básica, Coordenação Nacional de Saúde Bucal. Projeto SB Brasil 2010 Condições de saúde bucal da população brasileira 20092010. Resultados Principais.Brasília, DF: MS; 2012.

6. Starfield B. Atenção Primária: equilíbrio entre necessidades da saúde, serviços e tecnologia. Brasília, DF: Ministério da Saúde; 2004. Co-publicação UNESCO. 
7. Paim J, Travassos C, Almeida C, Bahia L, Macinko J. O sistema de saúde brasileiro: história, avanços e desafios. Saúde no Brasil 1: O sistema de saúde brasileiro. Lancet. 2012;6736(11):11-31.

8. Oliveira RFR, Souza JGS, Haikal DS, Ferreira EF, Martins AMEBL. Equidade no uso de serviços odontológicos provenientes do SUS entre idosos: estudo de base populacional. Ciênc Saúde Coletiva. 2016;21(11):509-23.

9. Costa AM, Fonseca EP, Fonseca DAV, Sousa MRL. Distribuição espacial da xerostomia e índice de exclusão social de idosos de Piracicaba, SP. Arq Odontol. 2015;51(1);39-46.

10. De Amorim MRA, Antunes JLF, Sousa MLR, Peres MA, Frazão P. Prevalência e extensão da cárie dentária radicular em adultos e idosos brasileiros. Rev Saúde Pública. 2013;47(Suppl. 3):59-68.

11. Batista MJ, Rando-Meirelles MP, De Sousa MRL. Prevalência da cárie radicular na população adulta e idosa da região Sudeste do Brasil. Rev Panam Salud Publica. 2014;35(1):23-9.

12. López-Pintor RM, Casañas E, González-Serrano J, Serrano J, Ramírez L, De Arriba L, et al. Xerostomia, Hyposalivation, and Salivary Flow in Diabetes Patients. Diabetes Res. 2016:1-15

13. Neville B, Damm D, Allen C, Bouquot J. Patologia oral e maxilofacial. $3^{\mathrm{a}}$ ed. Rio de Janeiro: Elsevier; 2016.

14. Wolff A, Joshi RK, Ekström J, Aframian D, Pedersen AM, Proctor G, et al. A Guide to medications inducing salivary gland dysfunction, xerostomia, and subjective sialorrhea: a systematic review sponsored by the world workshop on oral medicine VI. Drugs Res Dev. 2017;17(1):1-28.

15. Moraes CA, Albuquerque LA, Chevitarese L. A importância da odontogeriatria para a oferta de cuidados bucais em idosos. Rev Rede Cuidados Saúde. 2017;10(1):1-9.

16. Rõsing CK, Jardim JJ. Cárie radicular: um problema odontológico crescente e de impacto. Clín Int J Braz Dent. 2016;12(1):84-7.

17. Krämer J. Prevalência e extensão de cárie coronária e radicular em adultos e idosos de Porto Alegre, Rio Grande do Sul, Brasil : resultados parciais [trabalho de conclusão de curso]. Porto Alegre: Universidade Federal do Rio Grande do Sul, Faculdade de Odontologia; 2016.

18. Carvalho APV, Silva V, Grande AJ. Avaliação do risco de viés de ensaios clínicos randomizados pela ferramenta da colaboração Cochrane. Diagn Tratamento. 2013;18(1):38-44.
19. Neppelenbroek KH, Pavarina AC, Palomari SDM, Sgavioli MEM, Spolidorio LC, Vergani CE. Effectiveness of microwave disinfection of complete dentures on the treatment of Candida-related denture stomatitis. J Oral Rehabil. 2008;35(11):836-46.

20. Webb BC, Thomas CJ, Whittle T. A 2-year study of Candida-associated denture stomatitis treatment in aged care subjects. Gerodontology. 2005;22(3):168-76.

21. Wyatt CCL, Maupome G, Hujoel PP, MacEntee MI, Persson GR, Persson RE, et al. Chlorhexidine and preservation of sound tooth structure in older adults. Caries Res. 2007;41(2):93-101.

22. Tan HP, Lo ECM, Dyson JE, Luo Y, Corbet EF. A randomized trial on root caries prevention in elders. J Dent Res. 2010;89(10):1086-90.

23. Zhang W, McGrath C, Lo ECM, Li JY. Silver diamine fluoride and education to prevent and arrest root caries among community-dwelling elders. Caries Res. 2013;47(4):284-90.

24. Cruz Gonzalez AC, Marín Zuluaga DJ. Clinical outcome of root caries restorations using ART and rotary techniques in institutionalized elders. Braz Oral Res. 2016;30(1):1-8.

25. Da Mata C, Finbarr P, McKenna AG, Cronin M, O'Mahony D, Woods N. Two-year survival of ART restorations placed in elderly patients: a randomised controlled clinical trial. J Dent. 2015;43(4):405-11.

26. Gil-Montoya JA, Guardia-López I, GonzálezMoles MA. Evaluation of the clinical efficacy of a mouthwash and oral gel containing the antimicrobial proteins lactoperoxidase, lysozyme and lactoferrin in elderly patients with dry mouth-a pilot study. Gerodontology. 2008;25(1):3-9.

27. Hakuta C, Mori C, Ueno M, Shinada K, Kawaguchi $\mathrm{Y}$. Evaluation of an oral function promotion programme for the independent elderly in Japan. Gerodontology. 2009;26(4):250-8.

28. Ohara Y, Yoshida N, Kono Y, Hirano H, Yoshida $\mathrm{H}$, Mataki S. Effectiveness of an oral health educational program on community-dwelling older people with xerostomia. Geriatr Gerontol Int. 2015;15(4):481-9.

29. Lyon JP, Da Costa SC, Totti VMG, Munhoz MFV, De Resende MA. Predisposing conditions for Candida spp. carriage in the oral cavity of denture wearers and individuals with natural teeth. Can J Microbiol. 2006;52(5):462-7.

30. Pereira-Cenci T, Del Bel Cury AA, Crielaard W, Ten Cate JM. Development of Candida-associated denture stomatitis: new insights. J Appl Oral Sci. 2008;16(2):86-94. 
31. Bergendal T. Status and treatment of denture stomatitis patients: a 1-year follow-up study. Eur J Oral Sci. 1982;90(3):227-38.

32. Maertens JA. History of the development of azole derivatives. Clin Microbiol Infect. 2004;10(Suppl. 1):1-10.

33. BRASIL. Ministério da Saúde, Secretaria de Atenção à Saúde, Departamento de Atenção Básica. Normas e manuais técnicos. Manual de especialidades em saúde bucal. Brasília, DF: MS; 2008.

34. Catalán A, Pacheco JG, Martínez A, Mondaca MA. In vitro and in vivo activity of melaleuca alternifolia mixed with tissue conditioner on Candida albicans. Oral Surg Oral Med Oral Pathol Oral Radiol Endodontol. 2008;105(3):327-32.

35. Mima EG, Vergani CE, Machado AL, Massucato EMS, Colombo AL, Bagnato VS, et al. Comparison of Photodynamic Therapy versus conventional antifungal therapy for the treatment of denture stomatitis: a randomized clinical trial. Clin Microbiol Infect. 2012;18(10):380-8.

36. Kraft-Bodi E, Jorgensen MR, Keller MK, Kragelund C, Twetman S. Effect of probiotic bacteria on Oral Candida in frail elderly. J Dent Res. 2015;94(Suppl. 9):181-6.

37. Polychronakis N, Yannikakis S, Zissis A. The Effect of repeated microwaving disinfection on the dimensional stability of acrylic dentures. Acta Stomatol Croat. 2014;48(4):279-84.

38. Skrīvele S, Care R, Bērziņa S, Kneist S, De MouraSieber V, De Moura R, et al. Caries and its risk factors in young children in five different countries. Stomatologija. 2013;15(2):39-46.

39. Slot DE, Vaandrager NC, Van Loveren C, Van Palenstein Helderman WH, Van der Weijden GA. The effect of chlorhexidine varnish on root caries: a systematic review. Caries Res. 2011;45(2):162-73.

40. World Health Organization. More oral health care needed for ageing populations. Bull World Health Organ. 2005;83(9):646-7.
41. Marques RA, Antunes JLF, Sousa MLR, Peres MA, Frazão P. Prevalência e extensão da cárie dentária radicular em adultos e idosos brasileiros. Rev Saúde Pública. 2013:59-68.

42. Griffin SO, Griffin PM, Swann JL, Zlobin N. Estimating rates of new root caries in older adults. J Dent Res. 2004;83(8):634-8.

43. Yee R, Holmgren C, Mulder J, Lama D, Walker D, Van Palenstein Helderman W. Efficacy of silver diamine fluoride for arresting caries treatment. J Dent Res. 2009;88(7):644-7.

44. Rong WS, Bian JY, Wang WJ, De Wang J. Effectiveness of an oral health education and caries prevention program in kindergartens in China. Community Dent Oral Epidemiol. 2003;31(6):412-6.

45. Ouanounou A. Xerostomia in the geriatric patient: causes, oral manifestations, and treatment. Compend Contin Educ Dent. 2016;37(5):306-11.

46. Demathe A, Silva ARS, De Carli JP, Goiato MC, Miyahara GI. Odontologia baseada em evidências: otimizando a prática e a pesquisa. RFO UPF. 2012;17(1):96-100.

47. Dotto JM. Avaliação da qualidade dos serviços de atenção primária à saúde acessados por idosos em dois distritos de Porto Alegre, RS, Brasil [trabalho de conclusão de curso]. Porto Alegre: Universidade Federal do Rio Grande do Sul, Faculdade de Odontologia; 2016.

48. Koray M, Ak G, Kurklu E, Issever H, Tanyeri H, Kulekci G, et al. Fluconazole and/or hexetidine for management of oral candidiasis associated with denture-induced stomatitis. Oral Dis. 2005;11(5):309-13.

49. Khozeimeh F, Shahtalebi MA, Noori M, Savabi O. Comparative evaluation of ketoconazole tablet and topical ketoconazole $2 \%$ in orabase in treatment of Candida-infected denture stomatitis. J Contemp Dent Pract. 2010;11(2):17-24.

50. Meurman JH, Pärnänen P, Kari K, Samaranayake L. Effect of amine fluoride-stannous fluoride preparations on oral yeasts in the elderly: randomised placebo-controlled trial. Gerodontology. 2009;26(3):202-9. 